REVISTA de

PEDAGOGIE

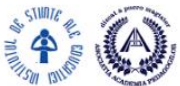

JOURNAL of

PEDAGOGY

http://revped.ise.ro

Print ISSN 0034-8678; Online ISSN: 2559 - 639X

\title{
ONLINE SCHOOLING IN RURAL AREAS IN ROMANIA \\ DURING THE PANDEMIC: TEACHERS' PERSPECTIVES
}

EDUCATIIA ONLINE ÎN ZONELE RURALE DIN ROMÂNIA ÎN PERIOADA PANDEMIEI:

PERSPECTIVELE PROFESORILOR

\section{Cristina TUNEGARU}

\author{
Journal of Pedagogy, 2021 (2), 101 - 120 \\ https://doi.org/10.26755/RevPed/2021.2/101
}

The online version of this article can be found at: https://revped.ise.ro/en/rp-2021-2/

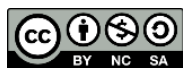

This work is licensed under the Creative Commons Attribution-NonCommercial-ShareAlike 4.0 International License.

To view a copy of this license, visit http://creativecommons.org/licenses/by-nc-sa/4.0/ or send a letter to Creative Commons, PO Box 1866, Mountain View, CA 94042, USA

Published by:

Centrul Național de Politici și Evaluare în EduCAȚie

UNITATEA DE CERCETARE ÎN EDUCAȚIE

https://www.ise.ro/

https://rocnee.eu/

Further information about Revista de Pedagogie - Journal of Pedagogy can be found at:

Editorial Policy: http://revped.ise.ro/editorial-policy/

Author Guidelines: http://revped.ise.ro/en/author-guidelines/ 


\title{
ONLINE SCHOOLING IN RURAL AREAS IN ROMANIA DURING THE PANDEMIC: TEACHERS' PERSPECTIVES
}

\section{Cristina Tunegaru*}

\author{
University of Bucharest, \\ Faculty of Psychology and Educational Sciences, \\ Bucharest, Romania \\ cristina.tunegaru@gmail.com
}

\begin{abstract}
Because of the threat of the Coronavirus pandemic, schooling in Romania moved in distance regime in March 2020. During the next school year, each municipality chose the scenario for each school - face-to-face schooling or online learning - according to the local number of infections. However, online education encountered many difficulties in terms of material and human resources, especially in rural areas. In this study we aim to explore rural teachers' perspectives about online schooling in Romania, during the Coronavirus pandemic. The data - obtained through a series of interviews and questionnaires - were collected from rural teachers working in various parts of the country.

In this study we propose to follow two main directions. First, we explore teachers' experiences concerning the access to material resources in the school and at home. The absence of proper digital equipment and the quality of the internet connection are two of the main concerns for policy makers. Second, the study focuses on educational practice, discussing teachers' accounts and experiences during two periods: March-June 2020 and the next school year, until present. We intend to explore rural teachers' experiences in depth, as rural was always disadvantaged in Romania's education system. This study is a starting point for further research of rural teachers' preparedness in Romania and the implications of online learning on rural teachers and students.
\end{abstract}

* PhD. Candidate, Faculty of Psychology and Educational Sciences, University of Bucharest, Bucharest, Romania. 
Keywords: online schooling, pandemic, rural, teachers' experiences.

\section{Rezumat}

Din cauza amenin ării pandemiei de Coronavirus, şcolarizarea în România s-a mutat în regim la distan ă, în martie 2020. În anul şcolar următor, autorită ile din fiecare jude au ales scenariul pentru fiecare scoală - scoală online sau fa ă în fa $\breve{a}$-în func ie de numărul de infectări la nivel local. Educa ia online a întâmpinat însă multe dificultă $i$ în ceea ce priveşte resursele materiale şi umane, în special în zonele rurale. În acest studiu ne propunem să explorăm perspectivele profesorilor din mediul rural despre scolarizarea online din România, în timpul pandemiei de Coronavirus. Datele - ob inute prin interviuri şi chestionare - au fost colectate de la profesori din mediul rural care lucrează în diferite păr $i$ ale ării.

In acest studiu ne propunem să urmărim două direc ii principale. În primul rând, explorăm experien ele profesorilor cu privire la accesul la dotările necesare la şcoală şi acasă. Absen a unui echipament digital adecvat şi calitatea conexiunii la internet sunt două dintre principalele preocupări pentru deciden ii de politici publice. In al doilea rând, studiul se concentrează pe practica educa ională, discutând experien ele profesorilor în cele două perioade: martie-iunie 2020 şi anul şcolar următor, până în prezent. Ne propunem să explorăm în profunzime experien ele profesorilor din mediul rural, deoarece mediul rural a fost intotdeauna dezavantajat în sistemul de învă ământ din România. Acest studiu este un punct de plecare pentru cercetări ulterioare privind pregătirea profesorilor din România şi implica iile învă ării la distan ă asupra profesorilor şi elevilor din mediul rural.

Cuvinte-cheie: experien ele profesorilor, pandemie, rural, şcoala online.

\section{Introduction}

Information technology has had a growing impact in education for the last decades and the concept of online education enjoyed sustained academic interest. Basilaia and Kvavadze (2020) define online education as any learning activity where "information technology and communications are used to help in the development and acquisition of knowledge from the different remote locations. It uses the internet and video/audio and text communication and software to create the learning environment" (p. 1).

Basilaia and Kvavadze (2020) further recognize several types of online 
learning: knowledgebase ("a set of lessons that are published on a website and have general instructions for learning that a student has to follow, with no support available"); online support ("a modified version of the knowledge base where the support is available so there is a discussion board, web forum or another communication way available to get support"); asynchronous training ("the lessons do not take place in real time, but the students are provided with content regularly"; support is given "through email or other communication platforms"); synchronous training ("done in real time with a live instructor and optional moderator"; "participants can communicate directly with the teacher and other group members"); hybrid training ("a combination of online and in-person interaction").

In this article we explore online schooling solely through the Romanian experience during the pandemic which is characterized by improvisation and haphazard measures aiming to replace traditional interactions, which were unexpectedly curtailed. For most rural schools this experience is composed of two periods. The first period is marked by a sense of insecurity, fear in the social reality of the pandemic. School closed at the beginning of the pandemic (March 2020), and there was little interest for developing an online approach to education during that specific school year, though certain attempts were made by teachers and policy makers. Soon after March 2020, some teachers started to organize distance learning sessions using the knowledge they previously had. By the end of the school year 2019-2020, only students who needed to pass national examinations returned to school in special conditions. By the beginning of the next school year, the online schooling context changed dramatically, as the majority of schools/municipalities in Romania had to organize some form of online classes, accordingly to the scenario they were assigned: hybrid or online. Education policy makers scrambled to supply digital equipment for disadvantaged students.

These periods lack a systematic approach to create a cohesive online learning infrastructure. Rather we see a simple transposition from the traditional regime to the virtual one using the same strategies and teaching methods. Exploring teacher's experiences of online teaching, Truzoli et al. (2021) show that "depression and stress are the main predictors of satisfaction level for online teaching" and "coping, locus of control and self-efficacy emerge as important protective factors". 
Kim and Asbury (2020) show that strong relationship between teachers and a sense of community in the school are essential in overcoming uncertainty. Their study explores teachers' experiences during the first five weeks of online teaching caused by the pandemic and it highlights teachers' worries about vulnerable students and the need for "more joined-up thinking from the government", "along with clarity from policy makers".

In this study we explore rural teacher's experiences in the two periods discussed, focusing on the access to digital equipment for students and teachers and on teacher's practice during the online classes, their perceptions, and accounts regarding online teaching. We focus on rural school mainly for two reasons. First, because rural education was always disadvantaged in comparison to urban education, due to high rates of poverty, teacher mobility, staff turnover, poor school infrastructure, school dropout (Horga et al., 2017; Merce et al., 2015). In rural areas, $30 \%$ of households lack internet access, and the service cost constitutes a significant financial disincentive for disadvantaged families (INSSE, 2020). For the 2019-2020 academic year, the dropout rate for rural middle schools stood at $1.9 \%$, significantly higher than $0.8 \%$ for urban schools; for primary schools the rural dropout rate was $1.7 \%$ (INSSE, 2021). The high rates of poverty and early school leaving in recent history can explain the educational success of the parents: rural parents graduate an average of 9.74 years of school and just $0.7 \%$ finish a form of higher education, versus 12.1 years and $18 \%$ for urban parents. (World Vision, 2020). Although several public policies target rural education in Romania (Ungureanu, 2018), reducing inequalities between rural and urban continues to be a challenge, as rural is "a disadvantaged environment" (Stanef \& Manole, 2013). Second, Romania is among the countries with high shares of the rural population at European level (Eurostat, 2021). Thus, concentrating on rural population, seen as a vulnerable group, is a necessary action especially during the pandemic.

\section{Methodology}

The survey conducted collected information through the use of interviews and questionnaires with teachers working in rural schools during the COVID-19 Pandemic. Teachers were approached via email or social 
networks, the only criteria of interest being teaching experience in a rural school during the reference period. The interviews took place via Skype, Zoom or phone, as agreed with each teacher and lasted approximately an hour. The interviews, which consisted of open-ended questions, were recorded, then transcribed.

We employed two tools of data collection - interview and questionnaire. In total we collected 18 interviews and 12 questionnaires. Initially the teachers in the sample were invited to interviews, however some on the teachers who expressed their interest about the research preferred a questionnaire. Therefore, by analyzing the interviews in the sample, a questionnaire was created and sent to the remaining 12 teachers. The interviews and the questionnaires focused on: their teaching experience during the pandemic, the level of support they enjoyed from the school and authorities, whether they had adequate material support, connectivity, etc. and skill development for online teaching, the students' attendance and methods to reach them outside online education, the involvement of the parents, the learning gaps the teachers observed among the students upon return to school and whether they will continue to use online teaching methods after the pandemic restrictions are lifted.

The questionnaire survey and the interviews were conducted from May 2021 to June 2021. The questionnaires were sent by email. Before they answered the questionnaire, participants were offered adequate information about the study, its objectives, and the processing of the data. Moreover, all participants have given their informed consent for the participation and the processing of the data for research purpose.

A first pass over the raw interview data was performed to collect salient issues. These were identified based on the author's experience with online teaching and relevant topics from the literature. This process may be prone to systematic bias. In a second reading, the data was coded in the themes previously identified.

We identified the following themes:

(a) Access to digital resources in school and at home.

(b) Internet connection difficulties and improper equipment. 
(c) The presence of poverty.

(d) Online schooling methods.

(e) Teachers' perceptions about parental involvement in the pandemic context.

(f) Students' motivation and participation in online classes.

(g) Learning gaps occurred due to the new configuration of schooling.

\subsection{Sample}

The sample consists of 30 teachers working in rural schools across the country. They were selected from a large body of rural teachers who were approached online and invited to take part in the research. In total, approximately 200 invitations were sent. The resulting sample is random and no attempt was made to correct for geographical overrepresentation of certain counties. There was no previous contact with any participant. Every teacher in the sample represents a different school.

Table no. 1 outlines the professional profile of the resulting sample: number of teaching years, number of rural teaching years, the subjects they teach, the county.

Table no. 1. Professional profile of rural teachers in the sample

\begin{tabular}{|c|c|c|c|c|}
\hline Teacher & $\begin{array}{c}\text { Total no. of } \\
\text { teaching } \\
\text { years }\end{array}$ & $\begin{array}{c}\text { No. of years in } \\
\text { the rural } \\
\text { school }\end{array}$ & Subject & County \\
\hline AN & 20 & 20 & $\begin{array}{c}\text { Primary school } \\
\text { teacher }\end{array}$ & Constan a \\
\hline AP & 6 & 5 & $\begin{array}{c}\text { Primary school } \\
\text { teacher }\end{array}$ & Maramureş \\
\hline CG & 10 & 10 & $\begin{array}{c}\text { Romanian } \\
\text { Language }\end{array}$ & Vaslui \\
\hline VC & 11 & 11 & $\begin{array}{l}\text { Romanian } \\
\text { Language }\end{array}$ & Suceava \\
\hline MAO & 2 & 2 & $\begin{array}{l}\text { Romanian } \\
\text { Language }\end{array}$ & Vâlcea \\
\hline MD & 2 & 10 & $\begin{array}{l}\text { Romanian } \\
\text { Language }\end{array}$ & Neam \\
\hline BV & 25 & $\begin{array}{l}\text { Romanian } \\
\text { Language }\end{array}$ & Iaşi \\
\hline
\end{tabular}




\begin{tabular}{|c|c|c|c|c|}
\hline Teacher & $\begin{array}{c}\text { Total no. of } \\
\text { teaching } \\
\text { years }\end{array}$ & $\begin{array}{c}\text { No. of years in } \\
\text { the rural } \\
\text { school }\end{array}$ & Subject & County \\
\hline DA & 34 & 34 & $\begin{array}{l}\text { Romanian } \\
\text { Language }\end{array}$ & Ialomi a \\
\hline $\mathrm{CZ}$ & 14 & 14 & $\begin{array}{l}\text { Romanian } \\
\text { Language }\end{array}$ & Buzău \\
\hline MT & 10 & 10 & $\begin{array}{l}\text { Romanian } \\
\text { Language; } \\
\text { English }\end{array}$ & Vaslui \\
\hline SM & 2 & 1 & $\begin{array}{l}\text { Romanian } \\
\text { Language; } \\
\text { English }\end{array}$ & Prahova \\
\hline LMI & 1 & 1 & $\begin{array}{c}\text { Romanian } \\
\text { Language; } \\
\text { French }\end{array}$ & Buzău \\
\hline $\mathrm{PP}$ & 3 & 1 & Informatics & Bacău \\
\hline $\mathrm{AL}$ & 5 & 4 & Mathematics & Dâmbovi a \\
\hline $\mathrm{AB}$ & 12 & 12 & Mathematics & Tulcea \\
\hline $\mathrm{CD}$ & 15 & 10 & Mathematics & Mureş \\
\hline TR & 35 & 35 & Mathematics & Teleorman \\
\hline $\mathrm{MG}$ & 6 & 6 & French & Vaslui \\
\hline MV & 19 & 14 & French & Olt \\
\hline IU & 24 & 20 & French & Giurgiu \\
\hline $\mathrm{MN}$ & 4 & 4 & French & Bacău \\
\hline GA & 9 & 9 & French & Olt \\
\hline $\mathrm{ZC}$ & 23 & 23 & English & Gala i \\
\hline $\mathrm{OB}$ & 27 & 20 & English & Tulcea \\
\hline MM & 2 & 2 & History & Giurgiu \\
\hline $\mathrm{CM}$ & 12 & 10 & History & Bacău \\
\hline $\mathrm{PO}$ & 3 & 3 & Geography & Neam \\
\hline RE & 15 & 10 & $\begin{array}{l}\text { Geography; } \\
\text { Sports }\end{array}$ & Iaşi \\
\hline $\mathrm{EF}$ & 4 & 2 & Counselor & Suceava \\
\hline $\mathrm{CB}$ & 36 & 20 & Science & Dolj \\
\hline
\end{tabular}

In addition, to describe the sample, we explored the remoteness of each rural school. The distance from the teacher's home to school is extremely important in a rural educational context, as schools can be more or less desirable for teachers. The further from the city, the more remote the school is considered. The table below illustrates the distance from home to school for the teachers in the sample. We did not request or recorded objective 
distance data such as distance in kilometers from home to school, duration of commute, etc. Rather we used subjective self-assessment because teachers understand and perceive distance differently, considering some objective criteria, as access to public transportation, access to important roads and motorways, etc. This information was considered relevant because proximity to the school can have an impact on teachers' motivation, their relationship with the local community and colleagues and a long commute is a strong incentive to prefer online schooling to face to face teaching.

Table no. 2. Distance from school to home

\begin{tabular}{|l|c|c|}
\hline & No. of teachers & Percentage \\
\hline Living in the village & 8 & $26 \%$ \\
\hline Living in the city close to the village & 16 & $53 \%$ \\
\hline Far from school & 6 & $21 \%$ \\
\hline
\end{tabular}

Finally, as seen in the table below, we have explored teachers' connection with the rural environment.

Table no. 3. Teachers' connection with the rural environment

\begin{tabular}{|l|c|c|}
\hline & No. of teachers & Percentage \\
\hline Have lived in a rural environment & 15 & $50 \%$ \\
\hline Live in a rural setting & 7 & $26 \%$ \\
\hline Never lived in a rural setting & 8 & $24 \%$ \\
\hline
\end{tabular}

\subsection{Limitations}

One main limitation is the size of the sample and its random nature. Also, some counties are not represented while others are overrepresented.

This study took place at the end of the second school year affected by the pandemic - 2020-2021 - when each school in Romania followed a particular path according to the infection rate in the locality and the changes this rate suffered. Some schools spend more time than others following the online scenario. Some rural schools experienced the hybrid system as defined in 
the Introduction, while others didn't. Given these factors, each school experienced this period differently. This study explores teacher's experiences beyond the particularities of the school scenarios. We do not take into consideration the time each school spent in the online or hybrid system.

\subsection{Objectives}

The aims of this study are: (1) to explore rural teacher's access to digital equipment; (2) to highlight the positive and negative experiences of rural teachers during the pandemic focusing on educational practice; (3) to underline rural teacher's needs in the context of digitalizing education; (4) to give voice to teachers to express their personal and professional challenges they faced during the COVID-19 pandemic.

\section{Results}

3.1. Access to digital resources in school and at home

One of the main concerns of online schooling is the absence of proper equipment for schools, students, and teachers. In order to ensure access to education for all children, national and local strategies were implemented during the 2020-2021 school year. The ministry of education has allocated nationwide 250000 devices with internet connection to children from disadvantaged backgrounds.

However, in this study, teachers complain about the quality of the ministry's equipment for various reasons. Some report the difficulties encountered by using them: "we received those wonderful tablets, which really were not good quality, and made our work very difficult after that. When the child who received that tablet from the ministry was connected, well, I wanted to involve him/her. In response, it created a terrible howling, whistles, grunts, woes and a fantastic noise and it was terrible from this point of view." (AP, Primary school teacher). 
Other teachers report that the tablets arrived too late and were of poor quality and were difficult to use: "The school obtained 312 tablets through the "Home School" program, but they came too late, they broke down very quickly." (CM, History Teacher, Bacău).

Some teachers dispute the usefulness of these equipment, arguing that very disadvantaged students aren't able to use them until the family has access to utilities: "they received equipment, but they don't have electricity at home, or they don't have internet and the internet on the tablet doesn't work" (MM, History teacher).

Local efforts and campaigns may respond better to children's educational needs. As it can be seen in the account below, the social context of the village can have a powerful impact on schooling during critical periods. In one village in Vaslui, the priest is an important figure in children's education, finding and implementing local solutions, so that every student can participate in online classes: "Most of the children had [tablets], because we asked the priest for help. In our village, there was a small campaign to collect functional, but no longer used, tablets or phones and they were given to the children. Also, the priest, topped-up prepaid phone cards every month [...]" (CG, Romanian language teacher, Vaslui). The priest acted not only as an educational liaison for the community, but he organized a special room in the church's courtyard where students could borrow tablets and use them to connect during online classes: "Others [students] were able to go to a place near the church, a larger room with tables and chairs. The priest installed a router and children who had no signal or no equipment, took some tablets left by the priest and connected from time to time". In this particular approach, the school and the priest worked together to encourage and support students. This Romanian language teacher reports that most of the students were able to participate in online classes due to the conjugate efforts of the teachers, priest and the community as a whole.

Teachers argue that many students in rural schools needed to use a phone to connect to classes, even though this equipment is not adequate. "It's difficult on the phone, it's tiny" reports one primary school teacher, who states that, in her class, just 10 students could afford a tablet or a laptop while the other 17 children could only use the phone. Some students claimed they are not allowed to use a phone of a parent to connect to online classes. As a consequence, one Informatics 
teacher $(\mathrm{AB})$ declares that at some point "2-3 students were present at the online class. Teach Informatics to them online! But with what? Even those who log on have just a pitiful phone to watch. It's terrible."

\subsection{The quality of the internet connection}

We have found that the great majority of teachers consider that the quality of the internet connection was rather poor in rural localities and became a source of inequalities: "Some children really weren't malicious, they just couldn't connect because they didn't have a signal" (CG, Vaslui). Internet connection difficulties were encountered even in urban contexts. MG, a French teacher shares that "even in my city I had bad days with almost no connection, but for example in the village of V., in January, there was none at all, the children had to deal with mobile data, if they could afford it; if they didn't, they could not participate". Access to online education was limited for some students due to lack of adequate internet connections. Thus, the families were required to spend on mobile data fees.

The internet connection was disturbed or absent for different reasons, as the following: the area is in a process of modernization and expansion of the cable network $(\mathrm{MN})$, a specific phone network has no coverage in the village (EF, school counselor; CM, History teacher, PO, Geography; IU, French language), teachers experience loss of connections at mid-day, disturbances (MV, French teacher; DA, Romanian language).

\subsection{Online classes and poverty}

Online teaching in rural communities poses specific challenges for students and teachers, given the poverty, deprivation and internal immigration. According to national statistics data, in "rural localities over half of the population is at risk of poverty or social exclusion" (Andrei, 2018). Furthermore, "the likelihood that a person in rural areas will be in such a situation is twice as big, compared to a person from the urban environment; $29 \%$ of the population from rural areas in Romania lives in conditions of absolute poverty" (ibidem). The deprivation is not only reflected in access 
to digital equipment but also in habitation conditions. Teachers report that many children live in overcrowded homes in which it is impossible to assure silence and privacy for each child during online classes. A Romanian language teacher specifies that, during the pandemic, even 3-4 children needed to stay in the same room during the winter and take part in online classes at the same time: "when you want to listen to your student, you also hear the younger brother as his teacher listens to him" (CG). This instance poses specific challenges both for the teachers and the students, the access to quality online education is limited for these students. To summarize, living conditions can profoundly impact education and children's participation and attainment during online classes.

Moreover, the participation in online classes can be affected by farming activities, especially in very poor villages. EF, a school counselor, reports that since the beginning of February 2021, children started to participate more in household activities at the expense of online schooling: "they went on the tractor, they plowed, it didn't matter they were in the $6^{\text {th }}$ or $7^{\text {th }}$ grade". Some older students in high schools and vocational schools transitioned to jobs and other remunerated activities: "when school went online, they left to work abroad. They simply went to work to make money, which is their main goal. They still connected from time to time because their teachers threatened to expel them, but there were many absences, hundreds of absences. I also know cases of children who worked there, locally, at the flower shop, at the hairdresser's, to make money".

3.4. Online schooling methods and the traditional school environment

Because the transition to online classes was sudden and unexpected, many teachers found themselves little prepared to create and organize suitable activities and strategies. Their previous digital skills, their creativity and their ability to learn and reinvent were put to the test.

The first period of online classes (March-June 2020) is described as full of enthusiasm, effervescence for students who participate in sharing their knowledge with the teachers. ZC, English teacher, reports that she is happy because her students helped her in understanding some computer "secrets". While some teachers report that they have had no help and support from 
school, local community or educational institutions, experiencing a form of abandonment (AN: "I participated in training courses on my own initiative and on my own money, I taught the lessons from home"), others claim they could rely on themselves or their colleagues (RE: "I taught myself; when I didn't know I asked my colleagues. We helped each other all the time"; DA: "Within the school, we collaborate very well, it's the school family. I was always in touch with my colleagues, for any problem and at any time.") or the principal (DA: "the principal made accounts for students and teachers on the Google Classroom"; PO: "A guide on access to the platform was developed, both for students and teachers"). Some teachers report that local authorities helped the school with digital resources and connectivity, while others complain they were left to their own devices.

Some teachers attempted to transfer traditional methods and strategies to online classes, by using, for example, white boards or computer graphic tablets: "I used a mini-board on which I explained the lessons as if it were a class board" (LMI, Romanian Language teacher); "all I needed was a graphics tablet and an internet connection" (CZ, Romanian Language); "I paid for a graphics tablet with my own money first, then my school bought one." (AB, Informatics). Others were creative in order to keep students engaged and attentive: "I came up with new things, with innovations and, you realize, that math class on the internet is one thing and drawing class is something else. And I went with interactive games, with things that would attract them" (EF, school counselor).

However, the majority of teachers think they will continue to use and integrate in traditional teaching some form of online activity, because they are easy to use $(\mathrm{MG})$ or because of the diversity of online resources.

\subsection{Parental involvement}

Parents played an important role in online classes and teachers recognize the need of more intense parental involvement during the pandemic. While many teachers in this study complain of lack of control over students' involvement, the responsibility of supervision during online school shifted towards parents and family. Although the size of the sample does not allow us to make generalizable inferences, the interviewed teachers report that 
primary school parents appear more involved, continually talking and interacting with the teacher so that students are present and they complete school activities they are assigned. To point, AN, a primary school teacher confesses of being proud of her work with preparatory class (6-year-old students) because "they learned to read and to write, which were my objectives". Furthermore, she adds: "with those who did not manage to connect today, tomorrow, the day after, I spoke on the phone, or the parents often came to me: "Miss, I'm coming to town because I have shopping to do". "Okay, let's give you another activity sheet, let me explain you what I did, so that you can show it to your child at home" (AN, Primary school teacher).

However, a plurality of middle school teachers in the sample (MG, French teacher; LMI, Romanian teacher; MM, History teacher; PO, Geography) report that while some parents were involved in the students' school life during the pandemic, many parents were absent. The words "lack of interest" is used by the majority of teachers when talking about some parents. MV, a French teacher reports that "Most of the parents seem involved. I had online meetings with them, but only the parents who came to school also attended online meetings; but other parents said relaxed that it was no problem that the child did not attend online classes, it was because he/she was sleeping, or he/she was tired!". Further, MV shows that some parents have a different understanding and perception about education than teachers and a common ground is difficult to establish: "some parents have the impression that, if they start contradictory discussions, endless and full of reproaches to the school and to the teachers in general, on the class groups, they are involved and interested in education!"

\subsection{Students' motivation and participation in online classes}

Motivation is a key issue in education and especially in online schooling. Teachers in the sample report that initially students expressed enthusiasm to learn and interact via internet, but these reactions quickly vanished and made room for weariness, boredom. EF, a school counselor, analyzes the two periods saying that "by the end of February [2021] they were so bored with movies, power point slides, absolutely everything that means an online lesson, that it was very difficult to motivate them to participate". 
In her study of learning in an online environment, Wong (2020) identifies two basic learning needs that are not compatible with online schooling: relatedness "an individual's desire and need to connect and create a bondage with people" (p. 2) and arousal - "the state of learners engaged in an activity" with "positive arousal enabling continuous effort and participation in learning (p. 2).

Students turning their camera off and limiting their interaction with their peers are expressions many teachers encountered "In the class where I am a teacher, I told them "Guys, turn on that camera so everybody can see you, you are not watching TV" and one of them said to me, "I listened to you like the radio, Miss" (AB, Informatics). This attitude is not only a manifestation of tiredness, but it can also have psychological consequences, children learning from home may experience isolation, loss of contact with peers, thus being sensitive for behavioral changes, isolation, anxiety and depression (Deolmi \& Pisani, 2020). However, as Dvorsky et al. (2020) argue, "some youth who experience peer victimization likely find time away from school allows for greater concentration on academics, in addition to improved one-on-one interactions with peers and family, and unexpected social connections".

Turning their cameras off is understood by teachers as signs of formally participating in the lesson, students losing the relatedness and the arousal: "They weren't turning on the camera and they weren't answering when called by name either. I could see they were connected, but they didn't answer." (EF, school counselor); "although the students did not have their cameras on, it was obvious that some were doing something else but attending class, and others appeared connected but never responded when called" (MV, French teacher).

\subsection{Learning gaps}

When speaking about the learning gaps students face when returning to traditional schooling, teachers concentrate on two directions: 1. loss of essential competences, abilities and skills in writing, reading-comprehension, calculus, a slowdown in thinking; 2 . loss or change of social and interactional skills and abilities. The table below illustrates the teacher's evaluations of the students' development. 
Table no. 4. Teacher's evaluations of the students' development

\begin{tabular}{|c|c|c|}
\hline & No. of teachers & Percentage \\
\hline Indubitable learning and behavioral gaps & 12 & $40 \%$ \\
\hline Some learning and/or behavioral gaps & 7 & $23 \%$ \\
\hline Stagnation & 9 & $30 \%$ \\
\hline Progress & 2 & $7 \%$ \\
\hline
\end{tabular}

One Romanian Language teacher (VC, Suceava) expresses her concerns for the lack of proper writing guidance, which puts at risk certain vulnerable age group students: "It seems to me that a lot has been lost for spelling. We have transmitted the information [to students], but because I could no longer see a notebook, I could no longer make a personal correction, show the students where they need to correct something, a lot has been lost."

Students which transitioned from primary to middle school during the pandemic may be more at risk in losing key stages in the development of reading and writing skills: "Especially for students in the 5th grade who went online when they were in the 4th grade, I notice some grammar mistakes that I don't know how I will be able to fix. Good students, I'm not talking about the weak ones, good students who get 9 and 10 [maximum marks]. So, they make some mistakes... Maybe [online schooling is] for older students, which already... but for the little ones there are gaps and, unfortunately, it is for the worse (VC, Romanian teacher).

When returning to traditional schooling, many teachers report they needed to teach again the same lesson taught online: "I even mentioned [to them]: "we did the subject, I don't know if you remember". And it really was obvious that they didn't know, last year the communication at that time was like this ... an exchange of messages on WhatsApp" (VC, Romanian teacher). When talking about the online classes of the second period (2020-2021 school year), one teacher (CG) uses the phrase "unnecessary energy consumption", explaining that the majority of the students were present online, but very few of them were present with their spirit. 
Some learning gaps are due to the students' non-participation in online classes, while others are generated and are bound to the particularities of the school subject, especially when students are faced with a new subject, they may find it difficult to understand and integrate new concepts and knowledge in the context on online interactions with the teacher: "Personally, I believe students lost a great deal, especially the 5 th grade students. For them this was the first year of study for the modern language II. A foreign language is learned by repeating the words, by the teacher correcting the deficient pronunciation, by songs and poems adapted to the theme of the lesson and to the students' age, by explaining several times grammar issues totally different from those of the Romanian language." (MN, French teacher).

Behavioral changes and fear for other people's reaction are reported by EF, school counselor: "they lost the ability to have a conversation, to socialize. I had children who apologized for sneezing and I said "why do you apologize?". It's something physiological, something tickled your nose, it doesn't necessarily mean that ... The children were so scared that they would be kicked out of class coughing or sneezing, these poor people abstained as much as they could." Some students, especially from vulnerable groups estranged themselves from school and, as some teachers report "those who missed online school continued not to come to school or to come episodically. They participated in some classes but not in other" (EF, school counselor).

\section{Discussion and conclusions}

In this study we explore rural teachers' experiences concerning online education during the two periods (March-June 2020; September 2020-June 2021). The study employs in-depths interviews and questionnaire and explores the following themes: (a) access to digital equipment; (b) internet connection; (c) the impact of poverty; (d) online schooling methods; (e) parental involvement; (f) students' motivation; (g) learning gaps. The research found that teachers' experiences were very diverse. Some teachers worry about the negative educational, emotional and behavioral impact online education may have on younger or vulnerable students. They recognize the importance of authentic interactions between students and students and teacher, many advocating for returning to traditional schooling. 
A general theme that can be observed is that there exists a fundamental disconnect between intent and potential of online learning and the teaching practice. Teachers try to replicate traditional interactions using online communication tools which does not respond to students learning needs, especially arousal and relatedness. Most teachers seldom use appropriate teaching methods adapted to the online medium, they lack the appropriate guidance and are not aware that they need it, while the students lack of engagement is justified as bad faith.

Online schooling in rural localities encountered difficulties related to the development of the educational system in Romania, school infrastructure, as well as teachers' preparedness for online classes. Many teachers in the sample report that schools were not adequately prepared for online schooling. Rural school ought to be properly equipped with both the digital and technological infrastructure in order to sustain online classes when they are required. Moreover, a functional internet connection is required in every rural school, including in remote areas, so that online classes are accessible to every student, regardless of their residence.

On the one hand, we have uncovered systemic difficulties for online schooling. They are related to digital resources, school infrastructure, internet connection in school and at home and poverty. On the other hand, there are difficulties attributable to teachers' preparedness for online schooling, as parental involvement in education, online teaching methods, students' motivation and learning gaps.

A concerning problem which emerges from the study is the risk that students who failed to acquire basic competences, such as writing and readingcomprehension, during the haphazard deployment of online learning in Romania, will continue to be affected throughout their academic life. Identifying and correcting such outcomes is of critical importance for policy makers.

Conversely, a positive development is that the majority of teachers developed skills which enable them to use and incorporate digital resources in face-to-face classes. 
Given the contested impact of central educational decisions during the pandemic, we consider that local, community interventions should be encouraged in order to assure that vulnerable groups can participate in education. Additional staff and resources are needed in many rural localities.

\section{References}

- Andrei, T. (coord.). (2018). România: un secol de istorie: date statistice. Editura Institutului $\mathrm{Na}$ ional de Statistică.

- Basilaia, G., \& Kvavadze, D. (2020). Transition to Online Education in Schools during a SARS-CoV-2 Coronavirus (COVID-19) Pandemic in Georgia. Pedagogical Research, 5(4), 1-9. https://doi.org/10.29333/pr/7937

- Deolmi, M., \& Pisani, F. (2020). Psychological and psychiatric impact of COVID19 pandemic among children and adolescents. Acta bio-medica: Atenei Parmensis, 91(4), 1-5. https://doi.org/10.23750/abm.v91i4.10870

- Dvorsky, M.R., Breaux, R., \& Becker, S.P. (2020). Finding ordinary magic in extraordinary times: child and adolescent resilience during the COVID-19 pandemic. European Child \& Adolescent Psychiatry, 30, 1829-1831.

https://doi.org/10.1007/s00787-020-01583-8

- Eurostat. (2021, September 6). Eurostat Statistics on rural areas in the EU. http://ec.europa.eu/eurostat/statistics-explained/index.php/Statistics_ on_rural_areas_in_the_EU

- Horga, I., Jigău, M., Apostu, O., Fartuşnic, C., \& Costache, L. (2017). La şcoală: o privire asupra participării la educa ie folosind analiza pe cohortă. Alpha MDN.

- INSSE. (2020). Population access to information and communication technology - Romania. https://insse.ro/cms/sites/default/files/field/publicatii/accesul_ populatiei_la_tehnologia_informatiei_si_comunicatiilor_romania_2020_0.pdf

- INSSE. (2021). The educational system in Romania - synthetic data. School/ university year 2019-2020. https://insse.ro/cms/sites/default/files/field/ publicatii/sistemul_educational_in_romania_2019_2020.pdf

- Kim, L.E., \& Asbury, K. (2021). "Like a rug had been pulled from under you": The impact of COVID-19 on teachers in England during the first six weeks of the UK lockdown. British Journal of Educational Psychology, 90(4), 1062-1083. https://doi.org/10.1111/bjep.12381

- Merce, I.I., Milin, I., Petroman, C., \& Ciolac, R.M. (2015). School Dropout - A Social Problem in Romania. Procedia - Social and Behavioral Sciences, 182, 623-628.

- Stanef, R.M., \& Manole, A.M. (2013). Educational System Gaps in Romania. Procedia - Social and Behavioral Sciences, 93, 794-798. 
- Truzoli, R., Pirola, V., \& Conte, S. (2021). The impact of risk and protective factors on online teaching experience in high school Italian teachers during the COVID19 pandemic. Journal of Computer Assisted Learning, 37(4), 940-952. https://doi.org/10.1111/jcal.12533

- Ungureanu, E. (2018). An analysis of educational policy measures for rural education. Revista de Pedagogie, 66(2), 103-126. https://doi.org/10.26755/RevPed/2018.2/103

- Wong, R. (2020). When no one can go to school: does online learning meet students' basic learning needs?. Interactive Learning Environments. https://doi.org/10.1080/10494820.2020.1789672

- World Vision Romania. (2020). - Cursa celor 30 de ani de educa ie în România rurală. https://worldvision.ro/wp-content/uploads/2021/06/Sumar-studiu.pdf

The online version of this article can be found at: http://revped.ise.ro/category/2021-en/

\section{$(c))$ BY-NC-SA}

This work is licensed under the Creative Commons Attribution-NonCommercial-ShareAlike 4.0 International License.

To view a copy of this license, visit http://creativecommons.org/licenses/by-nc-sa/4.0/ or send a letter to Creative Commons, PO Box 1866, Mountain View, CA 94042, USA.
Versiunea online a acestui articol poate fi găsită la: http://revped.ise.ro/category/2021-ro/

\section{$( c c ) \longdiv { e r - n e - z a }$}

Această lucrare este licen iată sub Creative Commons Attribution-NonCommercial-ShareAlike 4.0 International License.

Pentru a vedea o copie a acestei licen e, vizita $i$ http://creativecommons.org/licenses/by-nc-sa/4.0/ sau trimite i o scrisoare către Creative Commons, PO Box 1866, Mountain View, CA 94042, SUA. 